○特集 上皮細胞膜の特性と機能

\title{
浸透圧感受における細胞膜の生理的な役割と ナトリウム再吸収制御
}

\author{
新里直美 1,2$) * \cdot 丸 中$ 良典 1,2$)$
}

1）京都府立医科大学大学院 医学研究科 細胞生理学

干 602-8566 京都市上京区河原町通広小路上る梶井町 465

2）平安女学院大学 日本食育・健康研究所

干 602-8013 京都市上京区烏丸通下立売西入る

\section{Physiological Roles of Plasma Membrane for Sensing Osmotic Stress in the Regulation of ENaC-mediated $\mathrm{Na}^{+}$Reabsorption}

\author{
Naomi Niisato $^{1,2)} *$ and Yoshinori Marunaka ${ }^{1,2)}$
}

1) Department of Molecular Cell Physiology, Graduate School of Medical Science, Kyoto Prefectural University of Medicine

Kyoto 602-8566, Japan

2) Japan Institute for Food Education and Health, Heian Jogakuin (St. Agnes') University

Kyoto 602-8013, Japan

To sense an environmental change such as osmotic stress is crucial for cells to survive and adjust to a new environment. In the epithelium of distal nephron, basolateral hypotonic stress is known to stimulate epithelial $\mathrm{Na}^{+}$channel (ENaC)-mediated $\mathrm{Na}^{+}$reabsorption for recovery of normal plasma osmolality without hormonal regulation. On the other hand, hypotonic stress causes drastic cell volume changes; initial cell swelling followed by regulatory volume decrease (RVD). Recently an increase in membrane tension by the initial cell swelling is considered to play an important role in conversion of extracellular physical stress to intracellular chemical signals. In this review, we focus our study on possible roles of plasma membrane itself and membrane proteins such as mechano-sensitive (MS) ion channels and growth factor receptors in sensing extracellular osmolality (hypotonic stress) and leading to regulation of $\mathrm{Na}^{+}$reabsorption.

Key words : epithelium $/$ MS channel / membrane tension / phosphorylation / hypotonic stress

\section{1. はじめに}

生体には，体内環境である血漿の浸透圧・量・組 成の恒常性を維持する仕組みが備わっており，血漿

* Corresponding author

Tel: $075-251-5311$

Fax: 075-251-0295

E-mail: naomi@koto.kpu-m.ac.jp
の浸透圧が正常に維持されているのは，主にバソプ レッシン分泌と口渇の仕組みによると考えられてい る. 血漿の浸透圧変化は, 生体への電解質と水の出 入りのバランス変化により生じ, 前視床下部に存在 する浸透圧受容器によって感知され, 血漿浸透圧は, 下垂体後葉からのバソプレッシン分泌制御・腎皮質 集合管での $\mathrm{Na}^{+}$再吸收制御を介した精巧なフィード バック機構により調節されている. そこで, 本総説 では, 浸透圧感受という物理的な刺激の感受メカニ 
ズムにおける細胞膜の生理的役割について，皮質集 合管での $\mathrm{Na}^{+}$再吸収を介する血漿浸透圧制御を中心 に解説するとともに, 様々な浸透圧感受メカニズム についても併せて概説する.

\section{2. 多様な浸透圧感受メカニズムにおける膜 張力の役割}

多細胞生物を構成する細胞から細菌, 酵母のよう な単細胞生物に至るまで, 細胞は周囲の環境変化を 的確に感受して, 応答・適応しなければならない. そこで, 多くの生物・細胞は, 浸透圧変化を感受す る様々な仕組みを備えている.

\section{1 細菌の浸透圧感受メカニズム}

細菌での高浸透圧感受機構は, “two-component system”と言われている。これらのシステムは, “sensor” と “response-regulator” から構成されてお り, “sensor” 分子である histidine kinase は高浸透圧 刺激を感受して活性化され，分子内の histidine 残基 がリン酸化される.このリン酸基は “response-regulator” 分子へ転移されて, 最終的には転写の活性化 を介して高浸透圧環境適応へのスイッチが入ること になる ${ }^{1}$ 。 一方, 細菌での低浸透圧感受機構では, 機 械刺激受容チャネル (mechanosensitive ion channel; MS channel）が重要な役割を果たす。低浸透圧環境 に曝された細菌内に水が流入して膨張すると細胞膜 の張力が増大し, MS channelが活性化されて開口し, 細胞質の構成成分を放出することで浸透圧差を軽減 して破壊を回避する．また大腸菌などの MS channel には，小さな浸透圧差で活性化する $\mathrm{MscS}$ と大きな浸 透圧差で活性化する MscLという少なくとも 2 つのタ イプが存在し, 浸透圧差の大きさを認識することが でき，浸透圧差に応じて放出する細胞質量を制御す ると考えられる2（Fig. 1)．また MscLの構造解析に より, 膜の張力を介する gating modelが提唱され, 形質膜からの張力感受部位も同定されている ${ }^{2,3}$.

\section{2 酵母の浸透圧感受メカニズム}

出芽酵母も浸透圧感受システムとして, 原核生物 と同じ “two-component system” により浸透圧変化 を感受し, HOG MAPキナーゼ経路を活性化するこ とにより, 高浸透圧環境に適応する（グリセロール を合成して細胞内に蓄積し, 浸透圧差を軽減する). 活性化した Hog1 MAPキナーゼは細胞核に輸送され, 高浸透圧応答遺伝子群の転写誘導などを介して細胞 の高浸透圧適応を可能にする ${ }^{4}$. HOG 経路にはSho1 と $\operatorname{Sn} 1$ の 2 種の膜タンパク質から活性化シグナルを

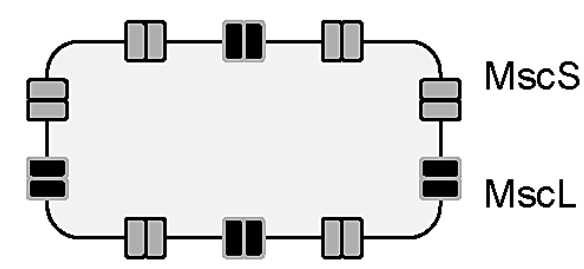

Hypotonic stress
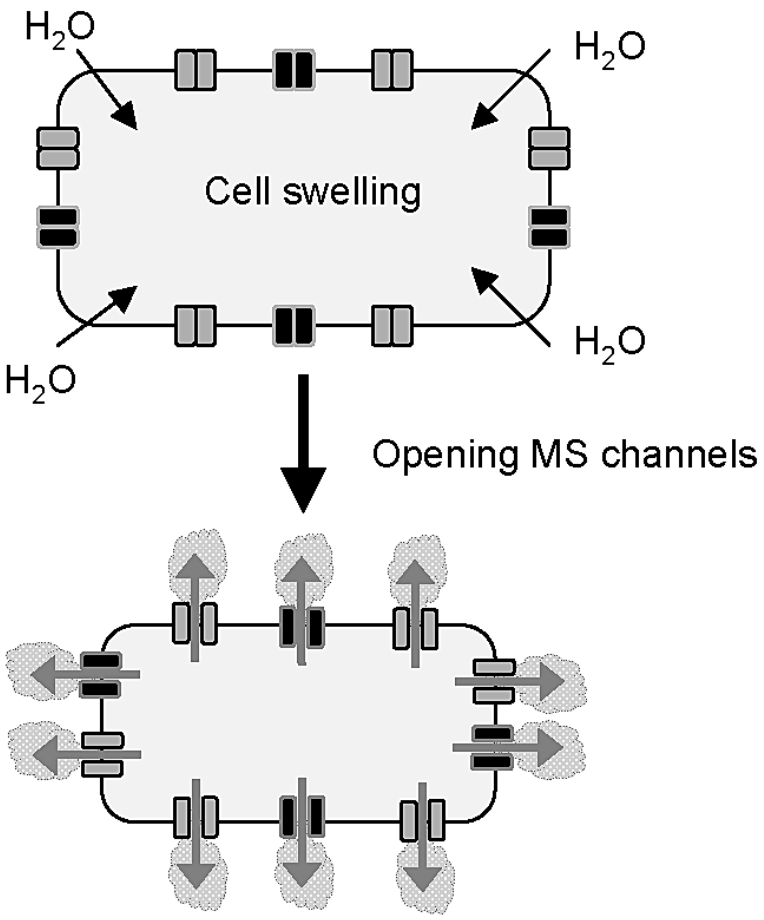

Release of cytoplasmic components

Fig. 1 Mechanosensitive (MS) ion channels in bacteria. When bacterial cells are subjected to hypotonic stress, they avoid cell lysis by releasing cytosolic components through opening MscS (mechanosensitive channel of small conductance) and MscL (mechanosensitive channel of large conductance).

伝達する独立した上流支経路（SHO1 経路と SLN1経 路）が存在する. 最近, SHO1支経路の最上位で働く 高浸透压センサーとして Hkr1, Msb2 という二つの 膜タンパク質が見出された. Hkr1/Msb2 は膜貫通ド メインを介して Sho1 と結合し, セリン・トレオニン に富み高度に糖鎖修飾された細胞外ドメインは活性 化を負に制御していることから, 高浸透圧感知の分 子機構として, $\mathrm{Hkr} 1 / \mathrm{Msb} 2$ 細胞外領域における糖鎖 のゲル構造が高浸透圧環境下で変化し, マスクされ ていたSho1 との相互作用ドメインがSho1 と結合し て活性化シグナルを細胞内に伝達する，という活性 化モデルが提唱されている5）（Fig. 2). 


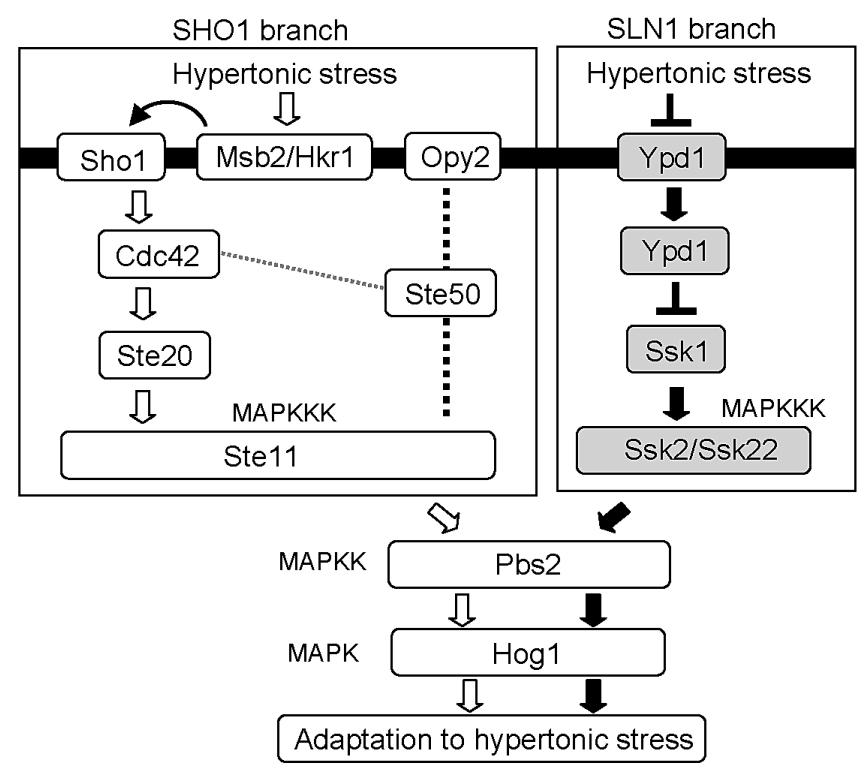

Fig. 2 Adaptive mechanisms to hypertonic stress in the budding yeast Saccharomyces cerevisiae. To cope with an increased external osmolarity, yeast synthesize, and intracellularly retain the compatible osmolyte glycerol. These events are governed by the high-osmolarity glycerol (HOG) signaling pathway, whose core element is the Hog1 MAP kinase cascade.

\section{3 高等真核細胞での浸透圧感受メカニズム}

これまでの研究で, 浸透圧刺激は, 細胞容積変化 を介した膜の張力変化として MSチャネル・容積感受 性チャネルなどに感知されると考えられている．MS チャネルは, 浸透圧以外にも伸展刺激や剪断応力な どの物理的な刺激を感知する. 多くの MSチャネルは カチオン $\left(\mathrm{Ca}^{2+}\right)$ 透過性チャネルであり, 活性化に 伴って細胞内への $\mathrm{Ca}^{2+}$ 流入を引き起こしてシグナル 伝達すると考えられている．このように，MSチャネ ル・容積感受性チャネルは, センサー分子として機 能し, 物理的な刺激を細胞内の化学的な分子へ変換 させてシグナル伝達すると考えられる．また，MSチ ヤネルは, 浸透圧変化に伴う膜の伸展刺激の大きさ を感知することができ, 細胞膜の伸展力（張力）の 大きさに応じて MSチャネル活性（開口確率 ; open probability ; $\mathrm{Po}$ ）が増大し, $\mathrm{Ca}^{2+}$ 流大量の変化として 感受する.さらに, 細胞膜を裏打ちして細胞の形態 や細胞内外の運動に必要な細胞骨格系も伸展刺激を 感受するメカニズムとして機能している ${ }^{6)}$. 例えば, 血管内皮細胞は，血圧変化に伴う周期的な血管の伸 展刺激の大きさと方向を感知して, 刺激方向と垂直 方向に細胞が走行する．この細胞応答には細胞骨格 系が関与しており, 現時点ではコフィリンによるアク チンの脱重合制御が重要であると考えられている7).
一方で, 容積感受性アニオンチャネルは, 細胞容 積膨張により活性化される外向き整流性クロライド チャネルとしてパッチクランプ法により同定されて おり, RVDの過程でのクロライドイオンの放出や細 胞内クロライドイオン濃度の制御に関与し, 浸透圧 変化への適応に貢献すると考えられている. しかし, その分子実体は未だに明らかにされていない.

\section{3. ホルモンによる血漿浸透圧制御}

血漿浸透圧が上昇すると，前視床下部に存在する 浸透圧受容器によって感知され, 下垂体後葉からの バソプレッシン分泌は充進する. バソプレッシンは, 腎臟の皮質集合管主細胞の $\mathrm{V}_{2}$ 受容体に結合して cAMPを産生する．細胞内に貯蔵されているアクア ポリンという水チャネルは, cAMP-dependent protein kinase（PKA）によりリン酸化されて管腔側（尿 細管内腔）膜上に挿入され, 管腔側膜の水の透過性 が著しく充進する ${ }^{8}$ )。一般に, 尿は低張（血漿浸透圧 より低い）のため, アクアポリン挿入後に, 尿細管 内の水は相対的に浸透圧の高い体内に移動し, 結果 として尿中からの水の再吸収を増大させて血漿浸透 圧を正常に戻す。

一方, 血漿浸透圧が減少すると, バソプレッシン 分泌は抑制され, 皮質集合管での水の再吸収を減少 させることで正常な血漿浸透圧を回復すると考えら れている. しかし，このような消極的なメカニズム 以外に, 血漿浸透圧物質である $\mathrm{Na}^{+}$を取り込む積極 的なメカニズムが必要ではないかと考えられる. 実 際に, 皮質集合管主細胞のモデル細胞として $\mathrm{Na}^{+}$再 吸収の研究に用いられているXenopus laevis A6 細胞 の細胞外浸透圧を低下させると, 直後より $\mathrm{Na}^{+}$再吸 収の克進は開始され，その後少なくとも 24 時間以上 にわたり, $\mathrm{Na}^{+}$再吸収の元進は維持される ${ }^{9,10)}$. この ように，ホルモン制御なしで $\mathrm{Na}^{+}$再吸収が増大し, 細胞自身が血漿浸透圧変化を感受して, その環境変 化に応答していることがわかる.

\section{4. 血漿浸透圧低下の感受と $\mathrm{Na}^{+}$再吸収制御}

\section{1 上皮膜を介する $\mathrm{Na}^{+}$再吸収}

皮質集合管の上皮膜を介する $\mathrm{Na}^{+}$再吸収は，バソ プレッシンやアルドステロンなどのホルモンによる 緻密な制御を受け, 生体内環境としての血漿の恒常 性維持や血圧調節に重要な役割を果たしていること が知られている。皮質集合管での $\mathrm{Na}^{+}$再吸収をはじ めとする上皮膜を経由するイオンの吸収や分泌は, 上皮細胞の極性に依存して局在しているイオンチャ 
ネルやイオン輸送体・ポンプを介した一方向性のイ オン輸送により可能となる. $\mathrm{Na}^{+}$再吸収は, 管腔側膜 に存在するアミロライド感受性上皮型 $\mathrm{Na}^{+}$チャネル （Epithelial $\mathrm{Na}^{+}$channel; $\mathrm{ENaC}$ ) を介する $\mathrm{Na}^{+}$流入過 程と血管側膜上に存在する $\mathrm{Na}^{+} / \mathrm{K}^{+}$ポンプ $\left(\mathrm{Na}^{+} / \mathrm{K}^{+}\right.$ ATPase）を介する $\mathrm{Na}^{+}$排出過程から構成されている. 一般的には, $\mathrm{ENaC}$ を介する $\mathrm{Na}^{+}$流入過程が, 経上皮 $\mathrm{Na}^{+}$再吸収の律速段階であると考えられており，バソ プレッシン, アルドステロン, 細胞外 (血漿) 浸透 圧など様々な $\mathrm{Na}^{+}$再吸収制御因子の標的とされてい る。また， $\mathrm{ENaC}$ を介する $\mathrm{Na}^{+}$流入量は，一定時間内 に $\mathrm{ENaC}$ が開口する確率として示される $\mathrm{ENaC}$ の活性 （Po）と細胞膜上の $\mathrm{ENaC}$ 数として示される発現量 （N）の積算（NPo）に依存する，従って， $\mathrm{ENaC}$ 介する $\mathrm{Na}^{+}$流入量は, 個々の $\mathrm{ENaC}$ の活性制御，及び $\mathrm{ENaC}$ 膜発現量制御により調節される.

\section{$4.2 \mathrm{ENaC}$ の trafficking を介する $\mathrm{Na}^{+}$再吸収制 御（早期の制御メカニズム）}

浸透圧低下刺激を与えた直後より増大する $\mathrm{Na}^{+}$再 吸収は, 細胞内のタンパク質輸送を阻害剂する brefeldin A（BFA）により著しく阻害され，パッチク ランプ法による測定では, 浸透圧低下刺激は $\mathrm{ENaC}$ の細胞膜上の発現数を $7 \sim 8$ 倍以上に増大させた.こ れらの観察事実は，浸透圧低下刺激が，細胞内に貯 蔵されていた $\mathrm{ENaC}$ を細胞膜へ挿入して, $\mathrm{Na}^{+}$再吸収 の律速段階を担う $\mathrm{ENaC}$ の細胞膜上の発現数を増大 させて, $\mathrm{Na}^{+}$再吸収を充進したと考えることができる. 我々の研究により, $\mathrm{ENaC} の$ traffickingには，上皮増 殖因子受容体 (epidermal growth factor receptor; EGFR）のチロシンリン酸化を介した活性化が重要 であることが示され，その下流には，EGFR-JNK (c-jun N-terminal kinase)-PI3 kinase というシグナ ルカスケートが関与することが明らかとなった ${ }^{10)}$ (Fig. 3)。このEGFRの活性化には, 細胞外浸透圧低 下による細胞容積膨張を介する細胞膜張力の増大が 必須であると考えられた，細胞外浸透圧低下による 一過性の容積膨張は, 一過性の EGFRの活性化を引 き起こした。一方，等浸透圧下で薬剤により細胞膜 張力を増大させたり，調節性容積減少（RVD）を抑 制して長期的な細胞容積膨張を引き起こすと， EGFR の活性化は長期的に観察され, 細胞容積依存的な EGFRの活性化が示唆された。これらのことから， $\mathrm{A} 6$ 細胞は細胞外の浸透圧変化を細胞容積依存的な細 胞膜の張力変化として感受し, 膜タンンパク質とし て存在しているEGFRの構造変化を介して活性化し, 細胞内へのシグナル伝達と細胞応答としての $\mathrm{ENaC}$ の traffickingを引き起こすと考えられる（Fig. 3).し
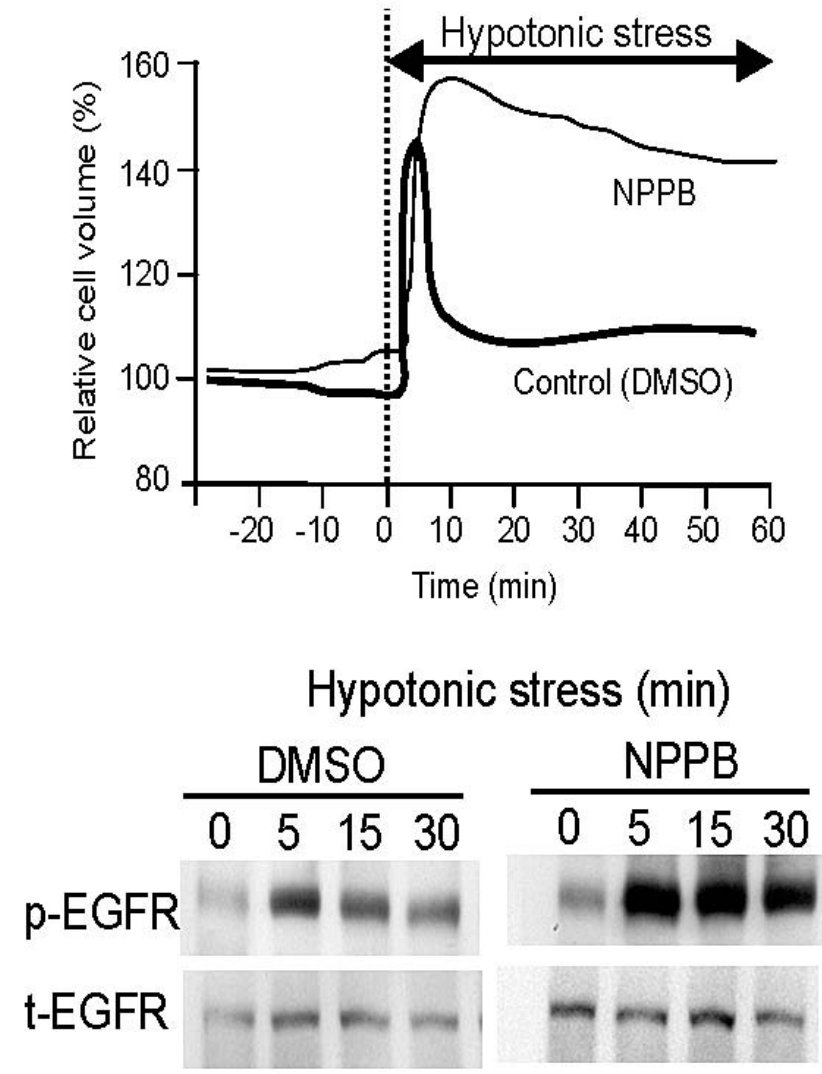

Fig. 3 A role of epidermal growth factor receptor (EGFR) for sensing hypotonic stress through cell volume changes. Hypotonic stress causes a transient activation of EGFR depending upon the initial, transient cell swelling. When RVD is prevented by blockade of $\mathrm{K}^{+} / \mathrm{Cl}^{-}$release with NPPB (a Cl- channel blocker), EGFR activation continues until recovery of the original cell volume. p-EGFR: phosphorylated (active) EGFR, t-EGFR; total-EGFR.

かし, 細胞内へ貯蔵されている $\mathrm{ENaC} の$ 量には限度 があり, 浸透圧低下の刺激が長時間継続されると, 新たな $\mathrm{ENaC}$ 産生の必要性が生じると考えられる。 実際，浸透圧低下刺激が 2 時間以上続くと， $\mathrm{ENaC}$ 介する $\mathrm{Na}^{+}$再吸収は，タンパク合成阻害剂に対する 感受性が時間とともに高くなり, 新たな $\mathrm{ENaC}$ が合 成されていることが示唆された。

\subsection{ENaC の転写制御を介する $\mathrm{Na}^{+}$再吸収制御 (後期の制御メカニズム)}

浸透圧低下刺激を長時間与えると，2時間を過ぎる 頃から $\mathrm{ENaC}$ を構成する $\alpha-, \quad \beta-, \quad \gamma-\mathrm{ENaC}$ のつ のサブユニットの mRNA発現レベルが著しく増大し, その後転写の亢進は少なくとも 24 時間までは維持さ れる ${ }^{11)} . \beta-, \quad \gamma-\mathrm{ENaC}$ の転写は, p38活性化依存的 に MAP kinase phosphatase-1（MKP-1）の転写を亢 進し，MKP-1が負の制御因子である ERKを不活性化 


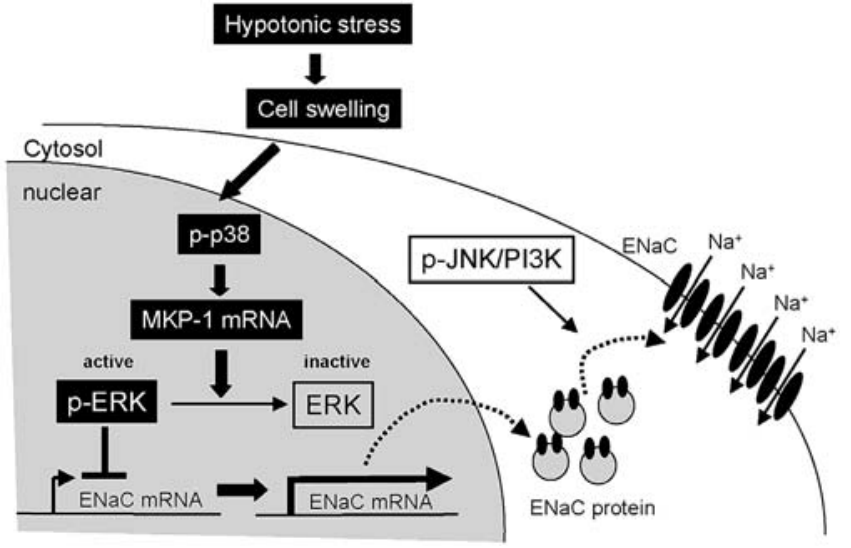

Fig. 4 A scheme of MAPK-dependent hypotonic regulation of $\mathrm{ENaC}-$ mediated $\mathrm{Na}^{+}$reabsorption in renal epithelial A6 cells. ERK suppresses $\mathrm{ENaC}$ gene expression as a negative regulator. Hypotonic stress releases $\mathrm{ENaC}$ gene expression from this suppression by induction of MAPK phosphatase-1 via a p38dependent pathway. In the hypotonic stress, JNK is also activated in the EGFR-dependent pathway that is involved in the translocation of $\mathrm{ENaC}$ to the apical membrane. The spatiotemporal regulation of MAPK family such as p38, JNK and ERK enables fine control of $\mathrm{ENaC}-$ mediated $\mathrm{Na}^{+}$reabsorption in $\mathrm{A} 6$ cells.

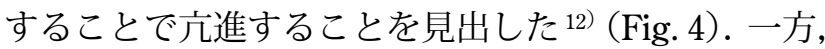
$\alpha-\mathrm{ENaC}$ の転写制御は， $\mathrm{Ca}^{2+}$ 依存的なシグナルによ り転写六進することも明らかとなった ${ }^{13)}$. 浸透圧低 下による p38活性化および $\mathrm{Ca}^{2+}$ 流入は，細胞容積膨 張により引き起こされ， $\mathrm{ENaC}$ の転写制御に関与する 浸透圧感受メカニズムにおいても, 細胞容積膨張に よる膜張力増大が重要な役割を担うと考えられる. 一方で，浸透圧低下時に，RVDを阻害して p38活性 化やMKP-1転写六進を恒常的に維持させても，それ だけでは $\mathrm{ENaC}$ 転写は六進しない。実際に，RVDの 過程では, 細胞内のクロライドイオン濃度 $\left(\left[\mathrm{Cl}^{-}\right]_{\mathrm{i}}\right)$ が減少することが明らかとなり ${ }^{14)}, こ の\left[\mathrm{Cl}^{-}\right]_{\mathrm{i}}$ 減少を フラボノイドや NPPBなどで阻害すると, $\mathrm{ENaC}$ の遺 伝子発現も阻害された ${ }^{15)} こ と か ら ，\left[\mathrm{Cl}^{-}\right]_{i}$ 減少も $\mathrm{ENaC}$ 転写元進に必要であると考えられる。これまで の我々の研究では, $\left[\mathrm{Cl}^{-}\right]_{\mathrm{i}}$ の低下は, タンパク質間の 結合親和性を制御する可能性があり，転写因子の結 合性やポリメラーゼなどの酵素と基質との親和性を コントロールすることで, 転写を効率よく進行・維 持させていることが想定される，従って，浸透圧低 下による $\mathrm{ENaC}$ 転写六進では, triggerとして p38の 活性化が必要であるが，同時に $\left[\mathrm{Cl}^{-}\right]_{\mathrm{i}}$ 減少も不可欠な 制御因子として機能している可能性が示唆されて いる.

\section{5. おわりに：浸透圧感受複合体としての細 胞膜}

これまでの多くの研究から, 浸透圧感受の最初の 重要なステップの1つは細胞容積変化を介する細胞膜 の張力変化である. 細胞膜には, 受容体・イオンチ ヤネル・トランスポーターなどの様々な膜タンパク 質が埋め込まれ, 膜張力変化に伴い, 直接的あるい は間接的に構造変化が引き起こされ，その変化が受 容体の活性制御，イオンチャネルの活性変化に結び つくことで浸透圧刺激が細胞内に伝達されると考え られる. 従って, 細胞膜は, 浸透圧感受システムを 組み込んだ複合体と考えることができる．細胞膜は， 細胞内外を物理的に隔絶する障壁として存在すると ともに, 外界からの物理的な刺激（浸透圧, 剪断応 力, 重力, 伸展力など) を感知するセンサー複合体 ととらえることができる。そして，膜タンパク質が 物理的な刺激を細胞内のシグナルへと変換する変換 器 (converter) の役割を担っているとも考えられる. この物理的な刺激感受システムは, 刺激の大きさを 膜張力の大きさとしてとらえることができるが，さ らに, 物理的な刺激感受の感度を向上させるための システムとして, 細胞接着と細胞骨格系が存在して いる．血管内皮細胞は，周期的な伸展刺激の大きさ と方向性を細胞膜の MSチャネルと細胞骨格系を介し て感知し, 伸展方向と垂直に細胞が走行する．この ように，高等な真核細胞では，刺激の大きさと方向 性を感受するシステムが構築され，より繊細で的確 な細胞応答を可能にしている. また, これらの物理 的な（機械的な）刺激としての浸透圧刺激が, 細胞 膜の張力を介して受容体を活性化し, $\mathrm{ENaC}$ の膜への 局在を亢進して膜発現量を増大させて，早期のナト リウム再吸収を亢進させるメカニズムについても本 総説で概説した. さらに, 長期的な刺激への対応と して, $\mathrm{ENaC} の$ 遺伝子発現六進作用発現においては, 1）一過的な膜の張力は浸透圧変化感受のトリガーと しての役割を担い, さらに2）浸透圧変化感受におけ る継続的な刺激のシグナルとして $\left[\mathrm{Cl}^{-}\right]_{\mathrm{i}}$ がその働きを 担い, 浸透圧低下刺激が解除されるまで, $\left[\mathrm{Cl}^{-}\right]_{\mathrm{i}}$ 低下 は維持され, $\mathrm{ENaC}$ 遺伝子発現六進も維持される.こ のように，時間的な観点から，刺激の感受を考える と, いくつかの感受システムが複合的に機能して, 各刺激感受情報をリレーし, より繊細で複雑な細胞 応答を可能にしていると考えられる。 


\section{文献}

1) Stock AM, Robinson VL, Goudreau PN : Annu. Rev. Biochem., 69, 183 (2000)

2) Yoshimura K, Nomura T, Sokabe M : Biophys. J., 86, 2113 (2004)

3) Akitake B, Anishkin A, Sukharev S : J. Gen. Physiol., 124, 143 (2004)

4) Saito H : Chem. Rev., 101, 2497 (2001)

5) Takebayashi K., Tanaka K., Yang HY, Yamamoto K, Matsushita Y, Tomida T, Imai M, Saito H : EMBO J., 26, 3521 (2007)

6) Hayakawa K, Tatsumi H, Sokabe M : J. Cell Sci., 121, 496 (2008)

7) Ono S : Int. Rev. Cytol., 258, 1 (2007)

8) Moeller HB, Olesen ET, Fenton RA : Am. J. Physiol. Renal Physiol., 300, F1062 (2011)

9) Niisato N, Eaton DC, Marunaka Y : Am. J. Physiol. Renal Physiol., 287, F932 (2004)

10) Taruno A, Niisato N, Marunaka Y : Am. J. Physiol. Renal Physiol., 293, F128 (2007)

11) Niisato N, Taruno A, Marunaka Y : Biochem. Biophys. Res. Commun., 358, 819 (2007)

12) Niisato N, Marunaka Y : J. Physiol. Sci., 61 (suppl), S32 (2011)

13) Taruno A, Niisato N, Marunaka $\mathrm{Y}:$ Am. J. Physiol. Renal Physiol., 294, F177 (2008).

14) Miyazaki H, Shiozaki A, Niisato $\mathrm{N}$, Marunaka $\mathrm{Y}: A m$. J. Physiol. Renal Physiol., 292, F1411 (2007)

15) Fujimoto S, Niisato N, Sugimoto T, Marunaka Y : Biochem. Biophys. Res. Commun., 336, 401 (2005)

(Received 5 September 2011;

Accepted 29 September 2011)

\section{著者略歴}

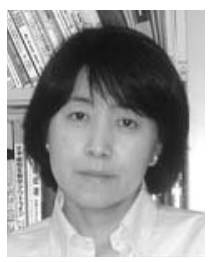

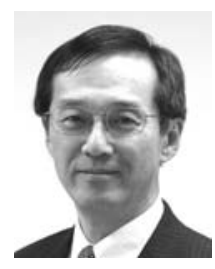

丸中 良典（まるなか よしのり）

1979年 3 月 京都府立医科大学 卒業

1979年 5 月 滋賀医科大学第二生 理学講座 助手

1985年 6 月 医学博士（京都府立 医科大学)

1986年 6月＼cjkstart米国テキサス大学 ガルベストン校医学 部生理学・生物物理 学講座 研究員

1986年 9月 米国エモリー大学 医学部生理学講座 研究員

1988年 7月 米国エモリー大学 医学部生理学講座 助教授

1990年11月 カナダトロント大 学医科学研究所 助 教授

医学部小児科学講座 呼吸器内科学／小児 病院研究所 助教授

1992年 7月 カナダトロント大 学医科学研究所 准 教授

医学部小児科学講座 呼吸器内科学／小児 病院研究所 准教授

2000 年 2 月 京都府立医科大学 第一生理学教室 教授

2003 年 4 月 京都府立医科大学大 学院医学研究科生理 機能制御学 教授 呼吸器病態制御学 教授

附属脳・血管系老化 研究センター神経化 学・分子遺伝学部門 教授（～平成19年） 学生部長（～平成 19 年)

2007 年 4 月 京都府立医科大学大 学院医学研究科細胞 生理学 教授 呼吸器内科学 教授 （～平成 22 年） 医学教育研究 セン ター長, 現在に至る

2011年 3 月 平安女学院大学日本 食育・健康研究所 所長, 現在に至る 